\title{
Differential Expression of Genes within the Cochlea as Defined by a Custom Mouse Inner Ear Microarray
}

\author{
Ken A. Morris, ${ }^{1}$ Einat Snir, ${ }^{2}$ Celine Pompeia, ${ }^{3}$ Irina V. Koroleva, ${ }^{2}$ Bechara Kachar, ${ }^{3}$ \\ Yoshinide Hayashizaki, ${ }^{4}$ Piero Carninci, ${ }^{4}$ M. Bento Soares, ${ }^{2}$ and Kirk W. Beisel ${ }^{1}$ \\ ${ }^{1}$ Department of Biomedical Sciences, Creighton University, 2500 California Plaza, Omaha, NE 68178, USA \\ ${ }^{2}$ Pediatrics-Genetics, Iowa University, Iowa, IA 52242, USA \\ ${ }^{3}$ Section on Structural Cell Biology, NIDCD/NIH, Bethesda, MD 20892, USA \\ ${ }^{4}$ Laboratory for Genome Exploration Research Group, RIKEN Genomic Sciences Center, Tsukuba, Japan
}

Received: 6 August 2004; Accepted: 19 November 2004; Online publication: 2 February 2005

\begin{abstract}
Microarray analyses have contributed greatly to the rapid understanding of functional genomics through the identification of gene networks as well as gene discovery. To facilitate functional genomics of the inner ear, we have developed a mouse inner-earpertinent custom microarray chip (CMA-IE1). Nonredundant cDNA clones were obtained from two cDNA library resources: the RIKEN subtracted inner ear set and the NIH organ of Corti library. At least 2000 cDNAs unique to the inner ear were present on the chip. Comparisons were performed to examine the relative expression levels of these unique cDNAs within the organ of Corti, lateral wall, and spiral ganglion. Total RNA samples were obtained from the three cochlear-dissected fractions from adult CF-1 mice. The total RNA was linearly amplified, and a dendrimer-based system was utilized to enhance the hybridization signal. Differentially expressed genes were verified by comparison to known gene expression patterns in the cochlea or by correlation with genes and gene families deduced to be present in the three tissue types. Approximately $22-25 \%$ of the genes on the array had significant levels of expression. A number of differentially expressed genes were detected in each tissue fraction. These included genes with known functional roles, hypothetical
\end{abstract}

Correspondence to: Kirk W. Beisel - Department of Biomedical Sciences - Creighton University 2500 California Plaza, Omaha, NE 68178, USA. Telephone: (402) 280-4069; fax: (402) 280-2690; email: beisel@creighton.edu genes, and various unknown or uncharacterized genes. Four of the differentially expressed genes found in the organ of Corti are linked to deafness loci. None of these are hypothetical or unknown genes.

Keywords: differential expression, cochlea, organ of Corti, spiral ganglion, lateral wall, deafness genes

\section{INTRODUCTION}

The majority of genes related to hearing loss can be classified into three major groups. In general, these are based on their functional roles, which are (1) stereocilia-based mechanoelectrical transduction, (2) $\mathrm{K}^{+}$ recirculation and conductances, and (3) the compositional integrity and function of basement membranes. These genes are mainly expressed in the sensory epithelium, their surrounding supporting cells, or the cellular components of the cochlear lateral wall (composed primarily of the stria vascularis and spiral ligament). The set of genes that are involved in stereociliary development and homeostasis is suggested to comprise a network of interactive proteins, which include myosin VIIa, harmonin, cadherin 23, protocadherin 15, whirlin, and Sans (Boeda et al. 2002; Ahmed et al. 2003; Kikkawa et al. 2003; Mburu et al. 2003; Weil et al. 2003; Siemens et al. 2004). Many of the deafness genes initially appeared to be uniquely expressed in the inner ear, but subsequent data showed that their expression is 
not restricted to the inner ear. These genes are nonetheless pertinent for inner ear function (Beisel et al. 2004). Hearing loss genes are grouped into syndromic and nonsyndromic forms based on the clinical manifestations of gene mutations. It is estimated that over $50 \%$ of the several hundred deafness loci are still unknown or uncharacterized. In the mouse, there exist at least 175 spontaneous or genetically manipulated hearing-impaired mutant lines carrying defective genes, with more being identified from the large-scale ENU-mutagenesis screen (Nolan et al. 2000; Kiernan et al. 2002; Rhodes et al. 2003). Studies of these genes and their effects require techniques spanning from behavior to the analysis of unique cell types of the ear and their structure-function aspects. An essential strategy for such an analysis requires the examination of all genes expressed in the ear that are potentially affected and is exemplified by microarray technologies.

DNA microarray analysis does provide a means to study genes at a whole-genome level and can be used to (1) estimate expression levels, (2) begin characterizing previously unknown genes, (3) analyze differential gene expression among tissues, cells types, or specific treatments, (4) analyze mutational variations of a gene, and (5) identify gene interactions through clustering. Although limited in number, microarray studies of the inner ear have ranged from being more general discussions of utilization of these techniques and approaches for the investigation of the inner ear (Lomax et al. 2000; Chen and Corey 2002a,b) to more specific applications involving gene discovery, tissue comparison, and clustering analyses for gene network identification (Chen and Corey 2002a,b; Cho et al. 2002; Abe et al. 2003; Hawkins et al. 2003; Hertzano et al. 2004; Iijima et al. 2004). These studies demonstrate the general use and benefit of microarray analysis as an analytical tool for such analyses.

A common problem of all these studies is the lack of cDNAs or oligonucleotides exclusively representing inner ear transcripts. This impacts on the identification of genes involved in the development and function of the inner ear in both overabundance of uninformative genes as well as the absence of relevant genes. Another major difficulty in microarray assessment is the necessity of obtaining sufficient quantities of starting tissue for the generation of microarray probes. This requirement has mandated the use of whole inner ear/cochlear preparations, which can effectively "dilute out" the identification and quantification of pertinent transcripts. Recent technical advances in amplification of transcripts (Baugh et al. 2001; Badiee et al. 2003) and probe signal (Capaldi et al. 2000) have drastically reduced the required amount of starting material.
Recently, various cDNA libraries specific to the ear were constructed and analyzed (Beisel et al. 2004; Pompeia et al. 2004) as well as the mouse cDNA encyclopedia (Okazaki et al. 2002). We constructed a cDNA microarray chip derived from cDNA libraries produced from the inner ear. Herein, we report the validation and utilization of this "inner-ear-pertinent" cDNA microarray chip to identify the relative expression levels of known deafness genes and potential inner-ear-pertinent transcripts. Through the use of dissected fractions from the mouse cochlea representing the organ of Corti (OC), the lateral wall containing the stria vascularis (LW), and the spiral ganglion neurons (SG), differentially expressed genes were identified and their relationship to deafness loci was assessed.

\section{MATERIALS AND METHODS}

\section{DNA preparation for printing}

Bacteria cultures in 96-well plates were allowed to thaw at room temperature for approximately $30 \mathrm{~min}$. Five microliters of each culture was added to a 96-well thin-wall PCR plate containing TE buffer $(10 \mathrm{mM}$ Tris, $1 \mathrm{mM}$ EDTA). The plate was then heated to $95^{\circ} \mathrm{C}$ for $10 \mathrm{~min}$, and an aliquot, $5 \mu \mathrm{l}$, of each supernatant was transferred to a fresh 96-well PCR plate and used to amplify the cDNA inserts.

Clone inserts were amplified in a Peltier thermal cycler (MJ Research, Inc., Waltham, MA) using a modified M13 primer set as described (Hegde et al. 2000). Amplification was performed in 26 cycles with an annealing temperature of $55^{\circ} \mathrm{C}$. The extension time was 6 min for the RIKEN inserts and 3 min for the NIH inserts. Following amplification, $5 \mu \mathrm{l}$ of each sample was run out on a $1 \%$ agarose gel, which was used to determine the percentage of inserts that produced a product and the number of products with multiple PCR bands. The remainder of each sample was precipitated and then stored at $4^{\circ} \mathrm{C}$ until printing.

\section{Slide preparation and printing}

Dry PCR products were resuspended in sterile water (Sigma-Aldrich, Corp., St. Louis, MO), and $5 \mu$ l was transferred using a Biomek FX robot (Beckman Coulter, Inc., Fullerton, CA) into 384-well plates containing $5 \mu \mathrm{l}$ DMSO (Sigma). The samples were printed in triplicate on Corning UltraGAPS slides with a Cartesian ProSys printer (Genomic Solutions, Ann Arbor, MI) and TeleChem Stealth pins (TeleChem International, Inc., Sunnyvale, CA). The relative humidity during the print was controlled at $40 \%$. A total of 21,888 spots were printed (7296 unique spots) with a 
TABLE 1

\begin{tabular}{|c|c|c|c|}
\hline \multicolumn{4}{|c|}{ Experimental microarray design: sample comparisons } \\
\hline \multirow[b]{2}{*}{ Mouse $I D^{a}$} & \multicolumn{3}{|c|}{ Dissect fraction comparisons } \\
\hline & $O C$ vs. SG & $O C$ vs. $L W$ & $L W$ vs. SG \\
\hline$A$ & OC $^{\text {b-Alexa }}{ }^{647} ;$ SG-Cy3 & OC-Cy3; LW' ${ }^{b}-A l e x a^{647}$ & LW-Cy3; SG ${ }^{\mathrm{b}}-\mathrm{Alexa} \mathrm{a}^{647}$ \\
\hline $\mathrm{B}$ & OC-Alexa ${ }^{647} ;$ SG-Cy3 & OC-Cy3; LW-Alexa ${ }^{647}$ & LW-Cy3; SG-Alexa ${ }^{647}$ \\
\hline $\mathrm{C}$ & OC-Cy3; SG-Alexa 647 & OC-Alexa ${ }^{647} ;$ LW-Cy3 & LW-Alexa ${ }^{647} ;$ SG-Cy3 \\
\hline $\mathrm{D}$ & OC-Cy3; SG-Alexa ${ }^{647}$ & OC-Alexa ${ }^{647} ;$ LW-Cy3 & LW-Alexa ${ }^{647} ;$ SG-Cy3 \\
\hline
\end{tabular}

${ }^{a}$ Note that tissue samples were isolated and RNA was amplified separately from each of the four mice listed.

${ }^{\mathrm{b}}$ The material isolated from one mouse (e.g., mouse A) was used in three comparisons, as indicated.

center to center distance of $200 \mu \mathrm{m}$. The printed arrays were then UV cross-linked at $250 \mathrm{~mJ}$ using a Stratalinker (Strategene) and stored in a desiccator at room temperature until used. An expiration date of 6 months was used for all microarray chips.

\section{Experimental design}

Three sets of comparisons were made: OC vs. LW, OC vs. SG, and LW vs. SG. Table 1 depicts each comparison and the usage of the tissue samples from four individual animals, designated as mice A-D. The experiments were designed to provide both biological and technical replications and to be compatible with various methods of data analysis (Churchill 2002).

\section{RNA extraction}

Tympanic bullae from four normal hearing "outbred" CF-1 male mice (4-5 weeks) (Harlan, Indianapolis,
IA) were dissected and immediately placed in cold Minimum Essential Medium (Invitrogen Corp., Carlsbad, CA) for fine dissection. Following removal of the temporal bone, the cochleae were dissected at $4^{\circ} \mathrm{C}$ to obtain large portions of the lateral wall (composed mostly of the stria vascularis and spiral ligament) and spiral ganglia and the whole $\mathrm{OC}$, as represented in Figure 1. The samples were placed in tubes containing RNA Later (Ambion, Inc., Austin, TX) and stored at $-20^{\circ} \mathrm{C}$. Note that tissue samples from different mice and from different cochlear regions were not combined. Rather, each sample was processed separately in all of the succeeding steps (RNA isolation, amplification, and probe generation).

For RNA isolation, tissue samples were transferred to lysis buffer, disrupted, and then homogenized using a QIAshredder column (QIAGEN Sciences, Inc., Germantown, MD). Total RNA was isolated using the Qiagen RNeasy Mini kit following the manufacturer's standard protocol. DNase treatment

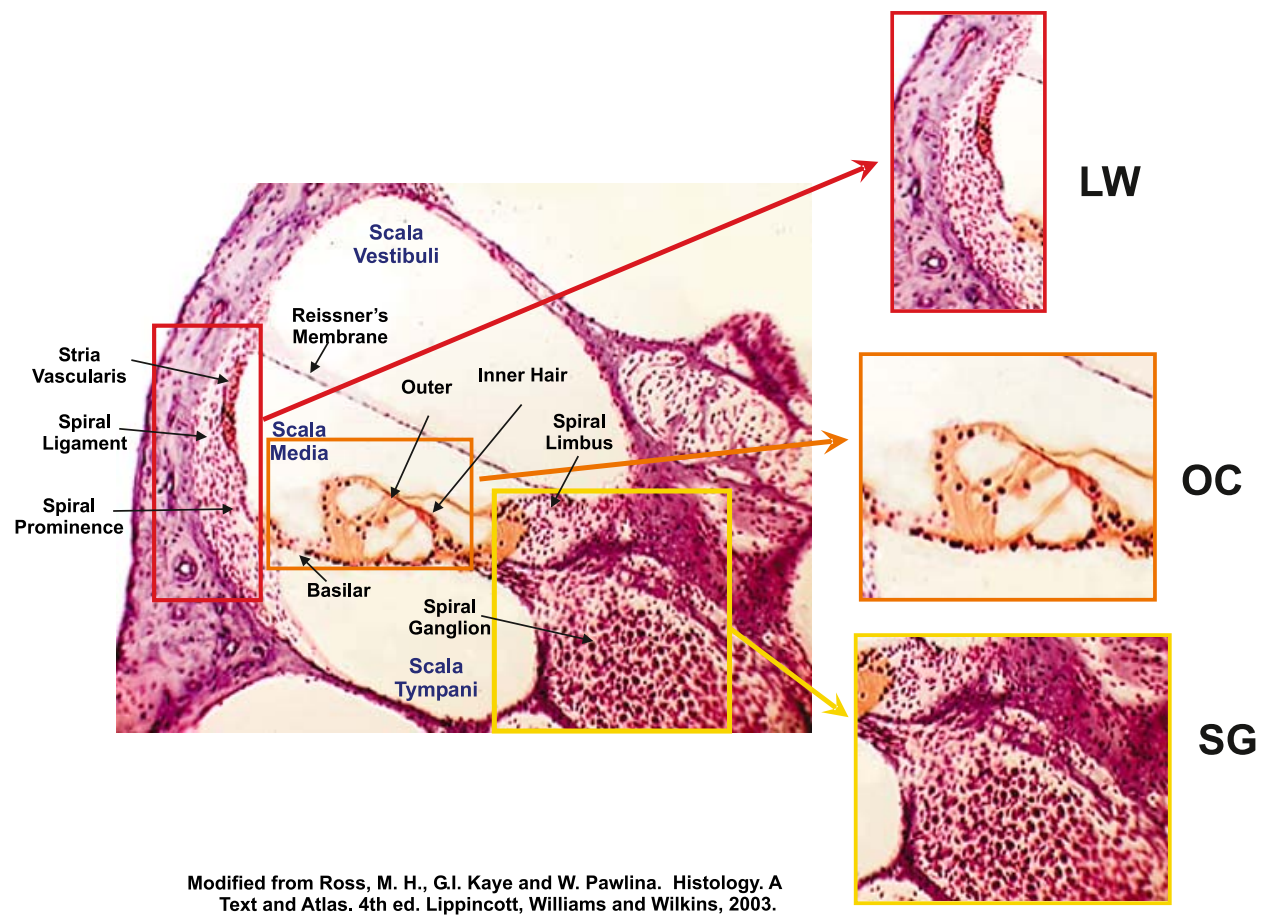

FIG. 1. Dissection of the mouse cochlea. A histological representation of the dissected fractions of the mouse inner ear is depicted. Three functionally distinct regions of the cochlea were chosen for isolation and represent the lateral wall (LW) comprising the stria vascularis, spiral ligament and spiral prominence, the organ of Corti (OC), and the spiral ganglion (SG) neurons. All samples are comprised of tissue from all three turns including the basal hook region. 
was performed on the column as described in the manufacturer's protocol. RNA integrity was verified using the Agilent 2100 Bioanalyzer with an RNA Pico Chip (Agilent Technologies, Palo Alto, CA) (see Figs. 2A and B). RNA concentration was determined with a UV spectrophotometer and also estimated with the Bioanalyzer.

\section{RNA amplification}

Amplified RNA (aRNA) was synthesized using one round of a T7-based linear amplification protocol as described (Van Gelder et al. 1990; Baugh et al. 2001). Specifically, approximately $50 \mathrm{ng}$ of total RNA was combined with $100 \mathrm{pmol}$ of a T7 Oligo(dT) primer (Ambion), and the sample was denatured at $70^{\circ} \mathrm{C}$ for 10 min. First-strand cDNA synthesis was performed by adding $5 \times$ first-strand buffer $(250 \mathrm{mM}$ Tris $-\mathrm{HCl}, \mathrm{pH}$ $\left.8.3 ; 375 \mathrm{mM} \mathrm{KCl} ; 15 \mathrm{mM} \mathrm{MgCl}_{2}\right), 1 \mu \mathrm{l}$ of $10 \mathrm{mM}$ dNTPs, $20 \mathrm{U}$ of RNasin (Promega Corp., Madison, WI), $2 \mu \mathrm{l}$ of $100 \mathrm{mM} \mathrm{DTT}$, and $200 \mathrm{U}$ of Superscript II (Invitrogen). The reaction was incubated at $42^{\circ} \mathrm{C}$ for $2 \mathrm{~h}$ with the addition of another $200 \mathrm{U}$ of Superscriptase II after $1 \mathrm{~h}$. The reaction was then heat inactivated at $60^{\circ} \mathrm{C}$ for $15 \mathrm{~min}$. Second-strand synthesis was performed using $5 \times$ second-strand buffer $[100 \mathrm{mM}$ Tris- $\mathrm{HCl}$, $\mathrm{pH}$ 6.9; $450 \mathrm{mM} \mathrm{KCl} ; 23 \mathrm{mM} \mathrm{MgCl}_{2} ; 0.75 \mathrm{mM}$ betanicotinamide adenine dinucleotide $\left(\beta-\mathrm{NAD}^{+}\right) ; 50 \mathrm{mM}$ $\left.\left(\mathrm{NH}_{4}\right)_{2} \mathrm{SO}_{4}\right], 4 \mu \mathrm{l}$ of $10 \mathrm{mM}$ dNTPs, $20 \mathrm{U}$ Escherichia coli
DNA Polymerase I (Invitrogen), 10 U E. coli DNA Ligase (Invitrogen), and $2 \mathrm{U}$ ribonuclease $\mathrm{H}$ (Invitrogen). The reaction was incubated at $16^{\circ} \mathrm{C}$ for $2 \mathrm{~h}$. Afterwards, the cDNA was purified and concentrated using the DNAclear kit (Ambion).

In vitro transcription was performed using the MEGAscript T7 kit (Ambion) by adding NTPs, 10× reaction buffer, and $\mathrm{T} 7$ enzyme to the purified cDNA. The resulting solution was incubated at $37^{\circ} \mathrm{C}$ for $14 \mathrm{~h}$. Afterwards, the aRNA was purified using the RNeasy Mini Kit (QIAGEN). RNA integrity was verified, and the concentration was determined as described above (see Fig. 2C). We were able to achieve greater than a thousand-fold amplification of the mRNA. Linear amplification of these samples was validated by their global expression data and comparing genes that are comparably expressed, such as housekeeping and ribosomal protein genes.

Probe synthesis, hybridization, and laser scanning A probe was generated for each of the 12 aRNA samples. A series of hybridizations was performed, with each probe being used in exactly two hybridization experiments as indicated in Table 1. For probe generation and hybridizations, we used the 3DNA 350 RP Kit (Genisphere Inc., Hatfield, PA), which utilizes a dendrimer-based strategy to enhance the signal (Capaldi et al. 2000). We followed the standard
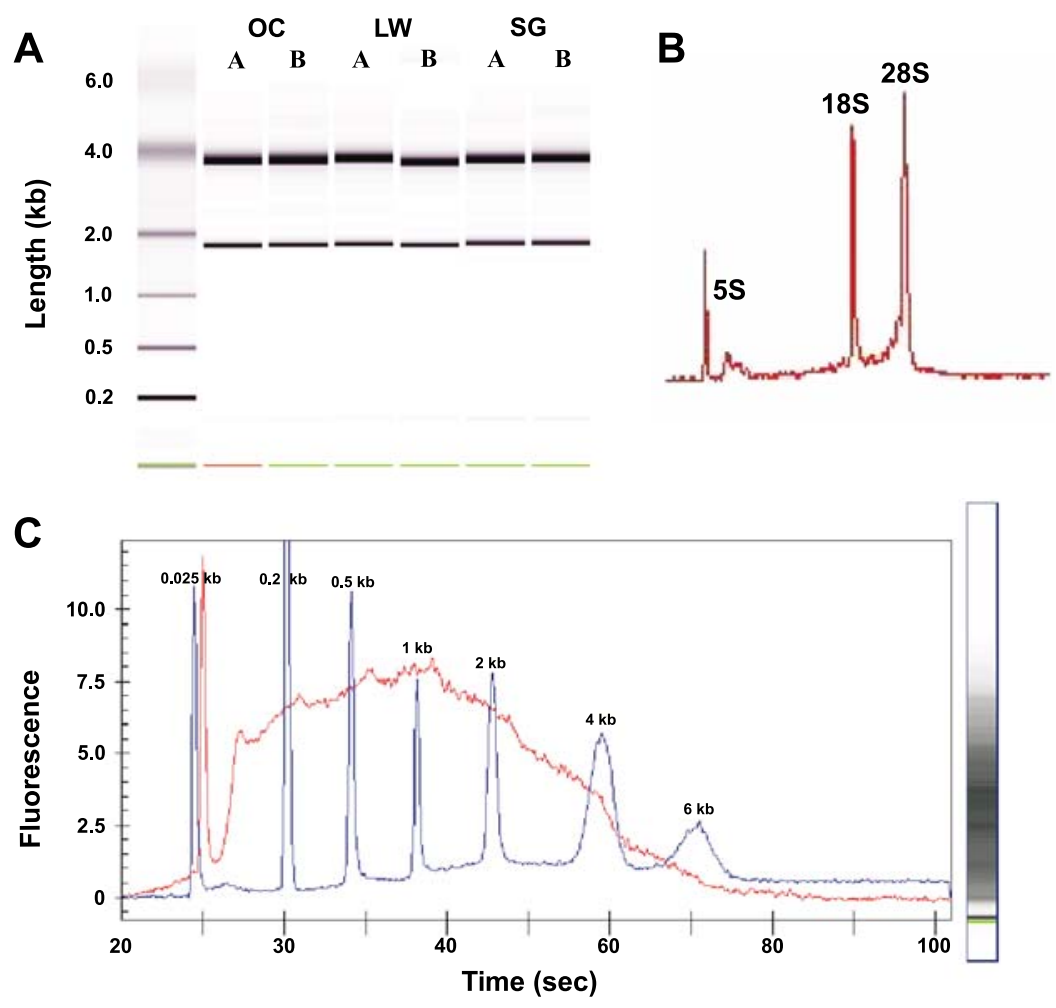

FIG. 2. Assessment of total RNA and amplified RNA samples. Quality assessment of total and amplified RNA. Bioanalyzer gel image (A) of total RNAs is represented by duplicated samples from each of the three dissected cochlear regions. In each sample, the $28 \mathrm{~S}, 18 \mathrm{~S}$, and $5 \mathrm{~S}$ ribosomal bands are visible, and this is depicted by the bioanalyzer electropherogram (B) of total RNA isolated from the OC. (C) Bioanalyzer electropherogram of $1 \times$ amplified RNA (aRNA) from the OC overlaid on the corresponding electropherogram of a 6 -kb RNA ladder (Ambion, Inc., Austin, TX). For all aRNA samples, the size range was about $100-6000$ bases, with a midpoint of about $1000 \mathrm{bp}$. 
protocol for probe generation for a dual channel experiment, beginning with $200 \mathrm{ng}$ of each aRNA sample. Briefly, RNA from each tissue was reversetranscribed into cDNA using unlabeled dNTPs. A capture sequence, which serves as the binding site for the fluorescent dendrimer, was ligated to the cDNA. The probes were combined and successive hybridizations were performed, first of the cDNA to the glass slide, then of the dendrimer mix to the cDNA. In both hybridization mixes, $3 \mu \mathrm{l}$ Mouse Cot1 DNA (Invitrogen) was added, and $16 \mu \mathrm{g}$ poly $\mathrm{d}(\mathrm{A})_{40-60}$ (Amersham Bioscience, Piscataway, NJ) was substituted for the dT blocker supplied in the kit. Both hybridizations were performed using the $2 \times$ formamide-based hybridization buffer at $50^{\circ} \mathrm{C}$. The hybridization times and posthybridization washes followed the recommendations in the protocol. Following hybridization, the slides were scanned with a GenePix 4000B laser scanner (Axon Instruments, Union City, CA) to determine the amount of each fluorescent cDNA that hybridized. Initial spot analysis and background subtraction were performed using the GenePix Pro 5.0 software (Axon Instruments).

\section{Normalization and background subtraction}

Background was calculated using a local feature background median, which was subtracted from each spot. Using this method, a background value is calculated for each feature individually based on the median intensity of pixels immediately surrounding the feature. A positive signal was defined as those spots with intensity levels greater than two standard deviations above background. The background-subtracted ratio of medians $(635 / 532)$ was calculated for each spot. These data were then normalized using locally weighted print-tip normalization (Yang et al. 2002) to transform each ratio into a log value.

\section{Data analysis}

Log-transformed values from locally weighted normalization were input into the Significance Analysis of Microarrays (SAM) program (Tusher et al. 2001).
Each comparison was input as a one class experiment, utilizing block permutations for the replicate spots on each chip. The delta value, which is used to set the cutoff point for significance, was adjusted to maximize the number of genes deemed significant while minimizing the number of false positives determined by the program. We found that there was a very narrow range for the delta value if we wanted to keep the number of false positives to a minimum.

\section{RESULTS}

\section{Microarray characterization}

Our mouse inner ear-pertinent custom microarray chip (designated CMA-IE1) is derived from the subtracted version of the RIKEN adult inner ear set (Unigene Library ID: 9974) and the NIH organ of Corti library (Unigene Library ID: 10920). As summarized in Table 2, the array is composed of 5758 of the RIKEN clones and 1288 NIH clones, all spotted in triplicate. The majority of the NIH clones on the array consist of unknown or uncharacterized ESTs to facilitate gene discovery. Clones were also added, both from the NIH library and from our own collections that are involved in important auditory pathways. In addition, the array contains a number of controls (buffer, mouse Cot1, polyA) and spikes for the purposes of normalization and data analysis. We define spikes as genes added to the array from various species (e.g., Xenopus laevis, Anopheles gambiae, Schistosoma mansoni, and Apis mellifera) that have been shown not to hybridize to any known mouse transcript. Approximately 60 different spikes were added to the microarray chip. Spikes can serve as negative controls or included in the hybridization mix to quantify the sensitivity of the assay.

Depending on the comparison, around $22-25 \%$ of the clones represented on the array showed positive signals greater than two standard deviations above background. This varied based on the cDNA source. Specifically, about $27-31 \%$ of the clones from the $\mathrm{NIH}$ library were detected at this level compared with

\begin{tabular}{lcrrrr}
\hline \multicolumn{5}{c}{ TABLE 2 } \\
\hline \multicolumn{5}{c}{ Microarray statistical analysis } \\
\hline Clone origin & Total number of clones & Number amplified & OC vs. SG & OC vs. LW & LW vs. SG \\
\hline NIH clones & 1288 & 1182 & $355(30.0 \%)$ & $320(27.1 \%)$ & $365(30.9 \%)$ \\
RIKEN clones & 5758 & 4589 & $1069(23.3 \%)$ & $912(19.9 \%)$ & $1120(24.4 \%)$ \\
"Lab" clones & 35 & 35 & $4(11.4 \%)$ & $4(11.4 \%)$ & $3(8.6 \%)$ \\
Total & 7081 & 5806 & $1424(24.5 \%)$ & $1232(27.1 \%)$ & $1488(25.6 \%)$ \\
\hline
\end{tabular}

${ }^{a}$ Not all the clones from the two libraries were represented on the microarray because the corresponding cDNA inserts could not be amplified using the combined rolling circle and PCR protocol of Hegde et al. (2000). 


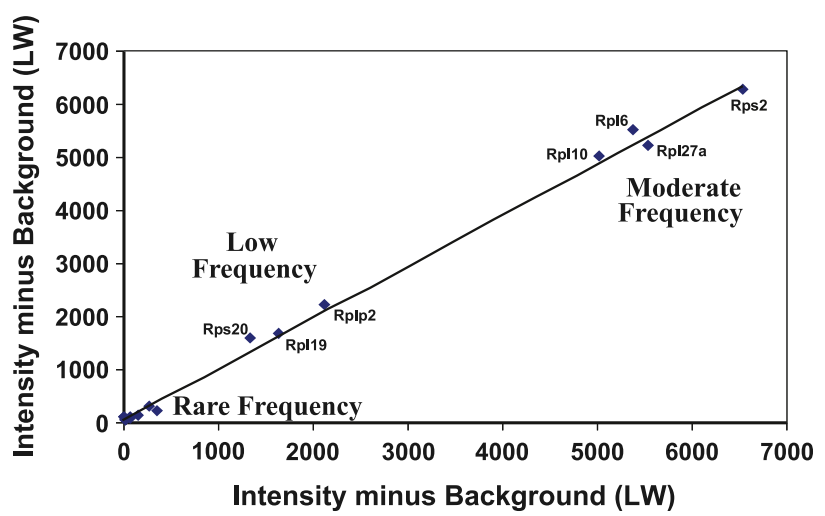

FIG. 3. Utilization of genes specifying ribosomal proteins in normalization assessment. Intensity levels of a large set of genes specifying ribosomal proteins present on the array were examined. Data are for one of the organ of Corti versus spiral ganglion comparisons, but similar results were observed across all experiments. The ribosomal protein genes were categorized into high $(>1000$ ESTs), moderate (>500 ESTs), and low (<250 ESTs) expression levels based on the number of ESTs in the entire mouse GenBank database. Genes with moderate and low expression levels were cytoplasmic ribosomal proteins and are designated. Those with background signal levels were mitochondrial ribosomal protein genes and are Mrpl10, Mrpl51, Mrps9, Mrps16, and Mrps19a.

about $19-24 \%$ of the RIKEN clones. For each comparison, the ratio of NIH to RIKEN clones detected was nearly the same. For the most part, we expected to see a fairly low level of detection. This is because the RIKEN inner ear set is highly subtracted and therefore consists of many genes expressed at low levels and/or only in specific tissues or cell types. The NIH organ of Corti unknown and/or uncharac- terized cDNA clones ranged from being singletons to those which are moderately expressed. Singletons are defined as cDNAs that were isolated only once in a given cDNA library. In addition, we expect many genes from the NIH library to be detectable in the immature ear of postnatal mice (postnatal days 5-13) and not in the adult cochlea because these cDNAs originate from mice at various developmental stages.

In general, low-frequency transcripts $(\sim 10-25$ copies/cell) were detected, whereas rare transcripts $(<10$ copies/cell) were not significantly above signal threshold to be classified as detectable. The limits of detection as defined by cellular transcript frequencies were ascertained by comparisons with the relative expression levels of housekeeping genes observed in reference control samples along with the clone frequency observed in the organ of Corti library (Pompeia et al. 2004). Because the organ of Corti library was not subtracted, the relative frequency of housekeeping and ribosomal protein transcripts within this library could also be inferred and compared with the corresponding cDNAs and their relative expression levels. One example of our microarray assay limit of detection is the observed expression of the nicotinic acetylcholine receptor $\alpha 9$ (Chrna9), which can be difficult to detect by in situ hybridization. Neither prestin nor Chrna10 was detected, and these genes are expressed at very low levels in the organ of Corti ( Judice et al. 2002). This is consistent with microarray experiments in general. There is usually a cutoff point for detection that is dependent on many factors, including the number of copies of a gene present in the probe and the methods used for
A

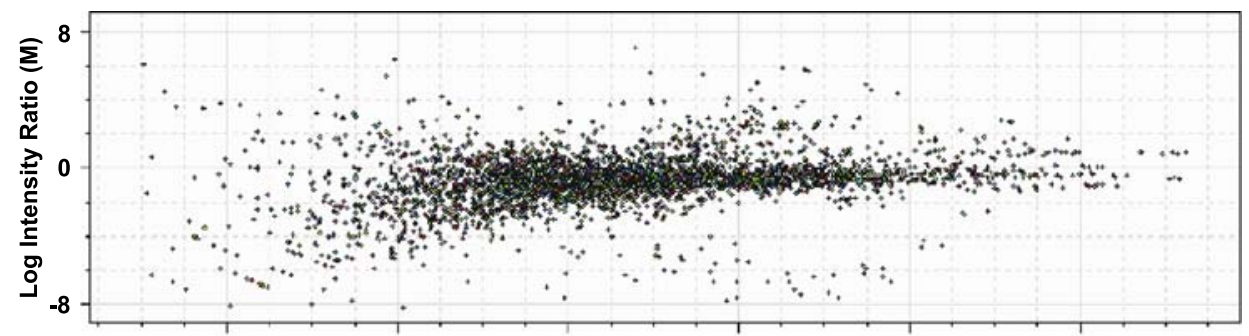

B

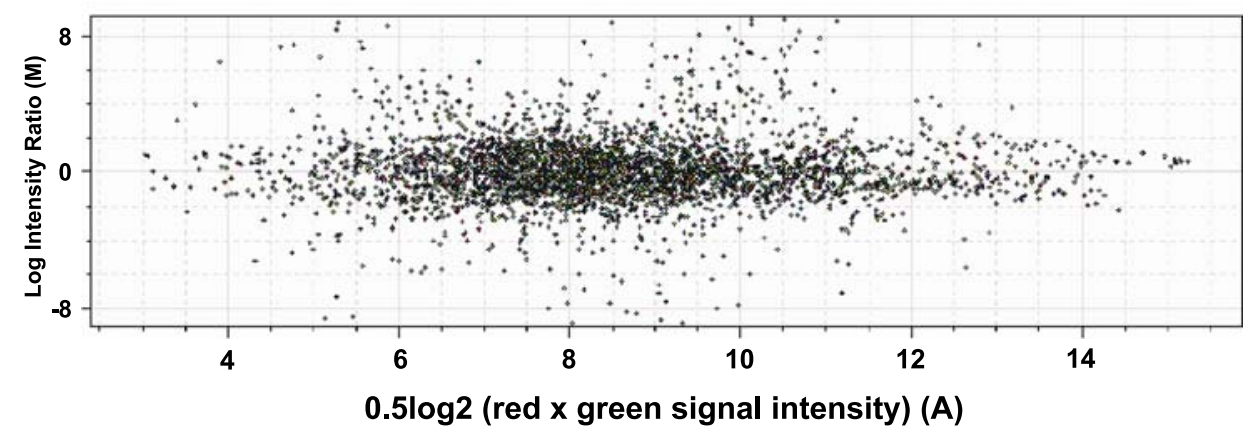

FIG. 4. Locally weighted (lowess) log ratio normalization of microarray data. A microarray comparison between SG (red signal) and LW (green signal) is shown. (A) A typical $\mathrm{M}$ versus $\mathrm{A}$ scatter plot of unnormalized microarray data. The $x$-axis is $0.5 \log 2$ (red intensity $\times$ green intensity) or A. The $y$-axis is $\log$ intensity ratio or $\mathrm{M}$. The $\log$ ratio values are skewed to the negative, especially at low intensities. (B) M versus A scatter plot of normalized microarray data. The distribution is now symmetrical about zero at all intensity values. Data are typical for all comparisons performed. 

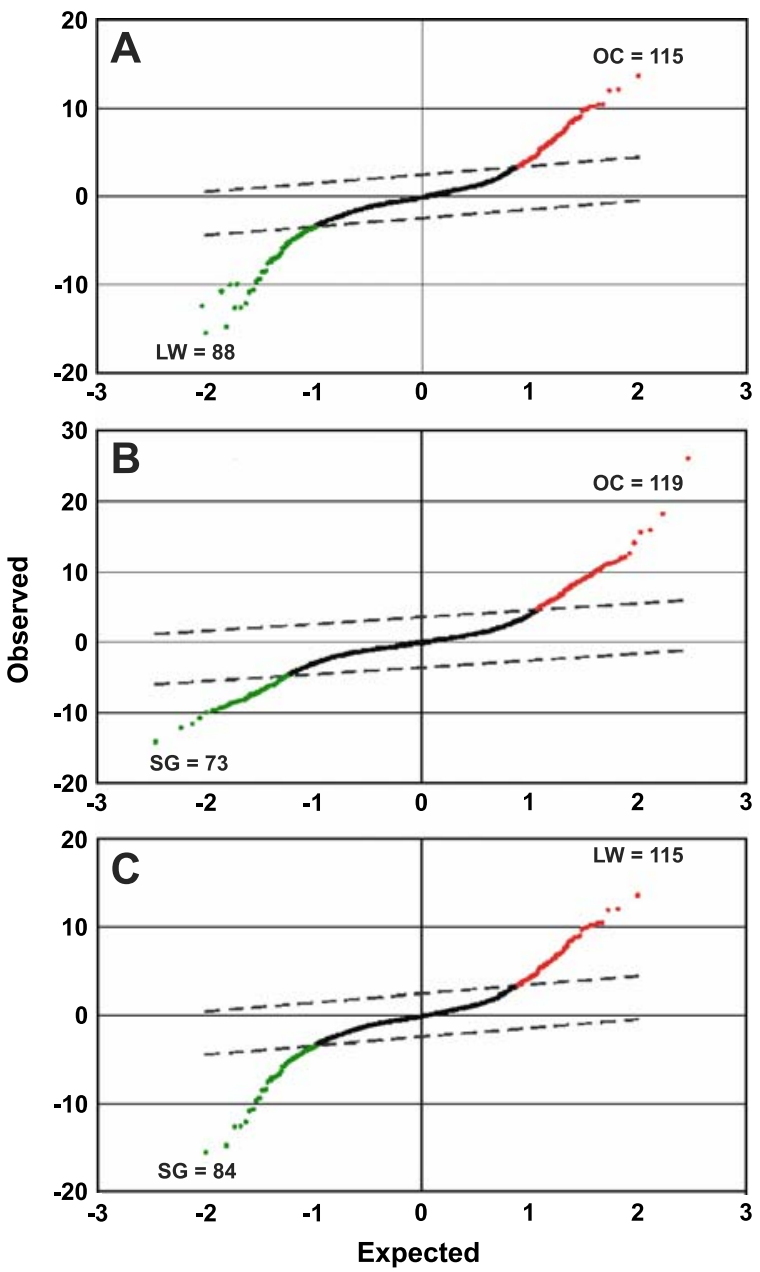

FIG. 5. SAM plots for cochlear dissected fraction expression comparisons. Comparisons were made between LW vs. OC (A), SG vs. OC (B), and SG vs. LW (C). For each comparison, the total number significant, median number false significant, and delta value are shown. Significant differentially expressed genes are represented by either green (tissue 1) or red (tissue 2) data points shown outside of the delta cutoff lines. The delta value is set to maximize the significant data points and minimize the false significant.

labeling and hybridization. The cutoff point can be estimated using spike controls (Badiee et al. 2003), which requires a great deal of planning, effort, and validation. Instead, we propose utilizing genes for ribosomal protein cDNAs present on the array as an internal standard. These genes were chosen because there are a relatively large number of them, and, for the most part, they are ubiquitously expressed. In addition, the mitochondrial ribosomal protein transcripts are considered to be rare transcripts. We found that the ribosomal protein gene expression levels could be used as an additional internal standard for estimating relative transcript frequency levels (Fig. 3). Interestingly, the relative expression levels observed in the microarray corresponded, in general, to the number of sequences of each of the ribosomal protein EST identified in the GenBank database. It must be recognized that their expression levels may vary among the different cell and tissue types, but their relative expression levels should not vary when comparing similar cellular or tissue samples. These factors also enable one to set up a QPCR standard curve to quantify expression levels of genes on the array based on their intensity levels. Genes for ribosomal proteins can also provide a good measure of overall assay sensitivity by comparing the intensity levels observed in any microarray experiment (Fig. 3). However, it is important that the lack of significant hybridization signal in our studies should not be taken to mean that there is no gene expression because the expression levels may be below the level of detection relative to other lowfrequency transcripts.

\section{Differential expression analyses}

For each comparison, locally weighted normalization produced at least 12 log-transformed values (4 hybridizations multiplied by 3 spots per slide) for every cDNA represented (see Fig. 4). These values were input into the SAM program and used to generate plots that determined which genes were significantly differentially expressed. Figure 5 shows SAM plots for each of the three comparisons. The delta values were adjusted to minimize the number of false positives while maximizing biological significance. The median false significant values were less than 0.5 , indicating that our data are reliable. In each case, slightly more than 200 genes were characterized as differentially expressed. However, this included genes that were represented on the array more than once. The number of unique genes characterized as differentially expressed was around 150 for each comparison. The OC showed the highest number of unique upregulated genes, followed by the LW, and then the SG. This makes sense considering the source of the cDNA spotted onto the array. In addition, the OC has a larger diversity of cell types and functions compared with the other two tissues.

Genes were identified that showed significantly higher expression in one tissue type compared with the other two. For example, genes upregulated in the OC for both the OC vs. LW and OC vs. SG comparisons were put into a group. We surmised that these genes may play an important functional role in their respective tissues. Table 3 shows the results of these data. Included are normalized SAM scores to compare the relative levels of differential expression. The OC group consists of several genes that do or may play crucial roles in hearing. These include otoancorin 
(Otoa) and transmembrane serine protease 3 (Tmprss3), which are both implicated in autosomal recessive deafness (Scott et al. 2001; Zwaenepoel et al. 2002). Also included are otoraplin (Otor), a possible deafness gene associated with the otic capsule (Cohen-Salmon et al. 2000), and otospiralin (Otos), which leads to hair cell degeneration and deafness in guinea pigs when downregulated (Delprat et al. 2002). The remaining genes in this group play diverse functional roles in the OC, and many have been shown to be expressed at relatively high levels in the OC compared with surrounding regions. One example is $S k p 1 a$, also known as organ of Corti protein $2(O c p 2)$, which is part of a novel SCF ubiquitin ligase complex involved in cochlear homeostasis (Liang et al. 1997).

The SG group consists of a large proportion of myelin-related genes, including $P l p, C n p 1, M a l, M p z$, and Fth. There are also a number of genes with other neuronal functions. For example, Ptgds is responsible

TABLE 3

\begin{tabular}{|c|c|c|c|c|}
\hline \multicolumn{5}{|c|}{ Organ of Corti differentially expressed genes } \\
\hline Unigene ID & Name & $\begin{array}{l}\text { No. Clones } \\
\text { on array }\end{array}$ & $\begin{array}{l}\text { Average SAM score } \\
\quad(S G \text { vs. OC) }\end{array}$ & $\begin{array}{l}\text { Average SAM score } \\
\quad(O C \text { vs. } L W)\end{array}$ \\
\hline Mm.244514 ${ }^{\mathrm{a}}$ & LOC327956: hypothetical LOC327956 & 1 & 15.8 & 15.9 \\
\hline Mm.55948 & $\begin{array}{l}\text { P2rx2: purinergic receptor P2X, ligand- } \\
\text { gated ion channel, } 2\end{array}$ & 1 & 11.9 & 15.6 \\
\hline Mm. $260192^{\mathrm{a}}$ & $\begin{array}{l}\text { LOC330483: similar to carcinoembryonic } \\
\text { antigen-related cell adhesion molecule } 1 \\
\text { (biliary glycoprotein) }\end{array}$ & 4 & 11.9 & 13.9 \\
\hline Mm.46561 & Lect1: leukocyte cell derived chemotaxin 1 & 3 & 16.7 & 5.5 \\
\hline Mm.259380 & St7ㄱ: suppression of tumorigenicity 7-like & 1 & 10.3 & 11.5 \\
\hline Mm. $231416^{\mathrm{a}}$ & $\begin{array}{l}\text { Similar to hypothetical protein FLJ38281, } \\
\text { clone MGC: } 38507 \text { IMAGE:5352880 (zinc } \\
\text { finger protein) }\end{array}$ & 1 & 11.0 & 10.4 \\
\hline Mm.219545 & Otos: otospiralin ${ }^{\mathrm{b}}$ & 2 & 13.6 & 7.0 \\
\hline Mm.148886 & Dspg3: dermatan sulfate proteoglycan 3 & 4 & 11.8 & 8.2 \\
\hline Mm.256058 & $\begin{array}{l}\text { MGC58343: hypothetical protein } \\
\text { MGC58343-ARM repeat structure } \\
\text { containing protein }\end{array}$ & 1 & 11.2 & 6.2 \\
\hline Mm.221073 & Otoa: otoancorin ${ }^{\mathrm{b}}$ & 5 & 7.2 & 9.3 \\
\hline Mm.330277 & $\begin{array}{l}0 \text { day neonate eyeball cDNA, RIKEN full- } \\
\text { length enriched library, clone: E130318F19 } \\
\text { product: unclassifiable, full insert sequence }\end{array}$ & 1 & 9.2 & 7.1 \\
\hline Mm.21109 & Gsn: gelsolin & 2 & 7.2 & 8.6 \\
\hline Mm.42944 & Skp1a: S-phase kinase-associated protein 1A & 1 & 8.6 & 6.6 \\
\hline $\mathrm{Mm} .27227^{\mathrm{a}}$ & $\begin{array}{l}\text { 5730469M10Rik: RIKEN cDNA } \\
\text { 5730469M10 gene }\end{array}$ & 2 & 6.4 & 8.1 \\
\hline Mm.29236 & $\begin{array}{l}\text { Lu: Lutheran blood group } \\
\text { (Auberger b antigen included) }\end{array}$ & 2 & 6.3 & 8.1 \\
\hline Mm.214638 & Tmprss3: transmembrane protease serine $3^{\mathrm{b}}$ & 2 & 6.1 & 8.2 \\
\hline Mm.309867 & Ptk9: PTK9 protein tyrosine kinase 9 & 1 & 6.1 & 8.2 \\
\hline Mm.29646 & Cn2: cytosolic nonspecific dipeptidase & 2 & 6.6 & 7.5 \\
\hline Mm.103738 & Cldn9: claudin 9 & 1 & 5.9 & 7.5 \\
\hline Mm.157751 & Oto2r: otoraplin ${ }^{\mathrm{b}}$ & 2 & 6.8 & 6.2 \\
\hline $\operatorname{Mm} .33849^{a}$ & $\begin{array}{l}\text { B630005N14Rik: RIKEN cDNA } \\
\text { B630005N14 gene }\end{array}$ & 1 & 4.8 & 8.2 \\
\hline Mm. $250438^{\mathrm{a}}$ & $\begin{array}{l}\text { 2310046G15Rik: RIKEN cDNA } \\
\text { 2310046G15 gene }\end{array}$ & 1 & 5.0 & 7.7 \\
\hline Mm.131074 & $\begin{array}{l}\text { Btbd14a: BTB (POZ) domain containing } \\
14 \mathrm{~A}\end{array}$ & 2 & 5.4 & 6.6 \\
\hline gi99h09 & No Unigene ID & 1 & 10.3 & 11.9 \\
\hline gi33a02 & No Unigene ID & 1 & 10.6 & 8.4 \\
\hline gi26a03 & No Unigene ID & 1 & 8.9 & 8.8 \\
\hline gi $14 \mathrm{c} 11$ & No Unigene ID & 1 & 8.8 & 8.6 \\
\hline gi35a07 & No Unigene ID & 1 & 5.9 & 7.7 \\
\hline F930021H19 & No Unigene ID & 1 & 5.5 & 7.1 \\
\hline
\end{tabular}

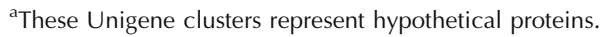

${ }^{\mathrm{b}}$ Deafness genes are indicated. 
for synthesis of brain-type prostaglandin D2, which is an abundant prostanoid in the central nervous system and a potent sleep-promoting substance in mammals (Onoe et al. 1988). Another example is Nrp, a receptor that mediates sensory pathfinding in the developing nervous system (He and TessierLavigne 1997). This selection of myelin-related and neuronal genes is consistent with our expectations for the SG, which is composed of nerve fibers innervating the hair cells of the OC. Based on expression analyses of $M p z, P l p$, and Erbb3 (Knipper et al. 1998; Lee et al. 2001; Hume et al. 2003), these genes should be highly expressed in SGs compared with the other dissected fractions. Similar to the immunostaining results, Erbb3 was present at higher levels in the SG compared with the OC fraction and was not detectable in the LW. A similar expression pattern was observed with $P l p$, which had significantly lower levels in the OC than the SG and was just above background in the LW. In situ hybridization studies demonstrated Plp mRNA in the cochle- ar oligodendrocytes but not in OC or LW (Knipper et al. 1998). Interestingly, a novel splice variant of collagen 1a1 (Col1a1), which uses an alternative polyadenylation signal, was identified and appears to be specific for the SG. It is listed in Table 4 under RIKEN clone ID F930112H09. The "typical" 3'NCR of Colla1 is present in all three dissected fragments at about the same levels. The functional importance, if any, of this novel splice variant is unknown.

In the LW set, two major functional groups of genes were identified. The first group is involved in maintaining ion concentration and regulation of fluids within the inner ear. These include Car2, Car14, Slc4a11, Ppp1r1b, and Atp1b3. The second group of genes is involved in cell growth, proliferation, and differentiation. These genes include $T g f b r 2$, Qscn6, and Ndr3. Again, these groups of genes are consistent with our expectations for the LW, which is involved in homeostasis of cochlear fluids and endolymph secretion, among other things.

TABLE 4

\begin{tabular}{|c|c|c|c|c|}
\hline \multicolumn{5}{|c|}{ Spiral ganglion differentially expressed genes } \\
\hline Unigene & Name & $\begin{array}{l}\text { No. of clones } \\
\text { on array }\end{array}$ & $\begin{array}{l}\text { Average SAM score } \\
\quad(S G \text { vs. OC) }\end{array}$ & $\begin{array}{l}\text { Average SAM score } \\
\quad(S G \text { vs. } L W)\end{array}$ \\
\hline Mm.1268 & Plp: proteolipid protein (myelin) & 2 & 15.8 & 13.1 \\
\hline Mm.347465 & Mpz: myelin protein zero & 4 & 10.5 & 16.7 \\
\hline Mm.56769 & Dcn: decorin & 1 & 10.2 & 10.4 \\
\hline Mm.39040 & $\begin{array}{l}\text { Mal: myelin and lymphocyte protein, T-cell } \\
\text { differentiation protein }\end{array}$ & 1 & 9.1 & 10.1 \\
\hline Mm.30837 & Ndr1: N-myc downstream regulated 1 & 1 & 6.1 & 12.5 \\
\hline Mm.15711 & Cnp1: cyclic nucleotide phosphodiesterase 1 & 8 & 9.2 & 9.3 \\
\hline Mm.1491 & $\begin{array}{l}\text { Fxyd1: FXYD domain-containing ion } \\
\text { transport regulator } 1\end{array}$ & 1 & 6.4 & 10.4 \\
\hline Mm.42095 & $\begin{array}{l}\text { Sfrp4: secreted frizzled-related sequence } \\
\text { protein } 4\end{array}$ & 1 & 9.2 & 7.2 \\
\hline Mm. $29358^{a}$ & $\begin{array}{l}\text { 2700055KO7Rik: RIKEN cDNA } \\
2700055 \mathrm{~K} 07 \text { gene }\end{array}$ & 1 & 11 & 5.1 \\
\hline Mm.1008 & Ptgds: prostaglandin D2 synthase (brain) & 3 & 8.7 & 6.9 \\
\hline Mm.290822 & $\begin{array}{l}\text { Erbb2: erythroblastic leukemia } \\
\text { viral oncogene homolog } 2\end{array}$ & 1 & 9.7 & 5.2 \\
\hline Mm.271745 & Nrp: neuropilin & 1 & 8.9 & 5.9 \\
\hline Mm. $41904^{\mathrm{a}}$ & $\begin{array}{l}\text { LOC } 382857 \text { : similar to hypothetical protein } \\
\text { FLJ90798 }\end{array}$ & 1 & 7.5 & 6.9 \\
\hline Mm.1776 & Fth: ferritin heavy chain & 2 & 8 & 6.2 \\
\hline Mm.196269 & $\begin{array}{l}\text { Golga7: golgi autoantigen, golgin } \\
\text { subfamily a, } 7\end{array}$ & 2 & 7.8 & 6.3 \\
\hline Mm.806 & Cd81: CD 81 antigen & 1 & 7.7 & 5.6 \\
\hline Mm.5167 & Nov: nephroblastoma overexpressed gene & 1 & 6.5 & 5.3 \\
\hline F930109M07 & No Unigene ID & 1 & 8.4 & 15.6 \\
\hline F930112H09 & No Unigene ID & 1 & 14.7 & 7.9 \\
\hline gi41a12 & No Unigene ID & 1 & 10.5 & 9.8 \\
\hline gi38f04 & No Unigene ID & 1 & 6.8 & 9.2 \\
\hline gi125h03 & No Unigene ID & 1 & 6.4 & 8.5 \\
\hline gi16d09 & No Unigene ID & 1 & 6.5 & 7.6 \\
\hline
\end{tabular}

${ }^{\text {a}}$ These Unigene clusters represent hypothetical proteins. 


\section{DISCUSSION}

To expand utilization of global expression analyses, baseline data of the normal relative levels and patterns of gene expression still need to be established for developmental stages and specific regions or cell types of the inner ear. Our custom microarray chip, CMA-IE1, represents an initial attempt at using a microarray designed specifically for the global expression of inner ear genes. cDNAs were primarily obtained from cDNA libraries with $\sim 20,000$ clones being analyzed (Beisel et al. 2004; Pompeia et al. 2004), where approximately 2000 transcripts were identified only in the inner ear and likely representing rare to low-frequency inner ear transcripts. These unique ESTs represent 2-3\% of the current mouse transcriptome encyclopedia (Okazaki et al. 2002; Carninci et al. 2003) and are not currently represented by any commercial microarray chip. This microarray increases our chances of finding new or novel genes involved in hearing or in development of the ear. As demonstrated in this study, four differentially expressed genes, Otoa, Otor, Otos, and Tmprss3, were identified that are associated with hearing impairment (Cohen-Salmon et al. 2000; Robertson et al. 2000; Ben-Yosef et al. 2001; Masmoudi et al. 2001; Scott et al. 2001; Delprat et al. 2002; Zwaenepoel et al. 2002). Although a number of unidentified singletons exhibited differential expression in the LW, OC, or SG, none were found to colocalize with a deafness locus (Beisel et al. 2004; Pompeia et al. 2004). Identification of functionally pertinent genes demonstrates the overall utility of the CMA-IE1 chip for further studies in spatiotemporal expression differences in normal and diseased inner-ear end organs, especially considering the representation of a large number of unidentified singletons and clusters. Reduction of the cellular complexity of the compared samples should also facilitate global expression analyses. Our goal is to develop a comprehensive set of transcripts pertaining to the inner ear on the array for identification of gene networks and arrangement of genes into functional clusters. Characterizing such pathways under normal or altered conditions requires the ability to screen many candidate genes simultaneously at different time points and under different experimental conditions.

A major hurdle for global expression analyses is the threshold of detection and the sensitivity of the microarray system to discriminate significant changes in expression of rare to low-frequency transcripts. Although a large number of low-frequency genes (10-25 transcripts/cell) can be detected, a number of inner-ear-pertinent genes are at or below this level of detection. The identification of both rare tran- scripts at $<10$ copies per cell and transcripts with limited but restricted expression within the different inner-ear cell types can be masked by assay noise generated by the general population. Limiting the transcript repertoire to a single cell population is a valid approach. However, obtaining a pristine cell population of at least 500 cells represents a technical challenge (Glowatzki et al. 1995; Zheng et al. 2000) and also requires linear amplification of the transcript repertoire. Linear amplification from a small number of cells does result in loss of specificity because of the production of shorter and shorter probes with each round of amplification (Scherer et al. 2003; Wilson et al. 2004). Biologically significant changes may still be undetectable by global analyses in the expression levels of inner-ear-pertinent genes. Nevertheless, quantitative PCR analyses for individual genes would be the method of choice to quantify these transcripts (Liberman et al. 2002; Stankovic and Corfas 2003).

Currently, only limited data are available for comparing our study with other inner-ear microarray studies, which primarily utilize commercially available chips. Expression analyses have been performed with an Atlas expression array (Clontech, Palo Alto, CA) containing 588 cDNAs, using 8- to 12-week-old rat whole cochlea and dissected fractions representing the modulus (MOD) and a combination of organ of Corti and lateral wall (OC-LW) (Cho et al. 2002). Sixteen differentially expressed genes were observed between rat MOD and OC-LW, and of these, only five genes (P2rx2, Plp, Pmp22, Limk1, and Nnat) were shared in common with our microarray. P2x purinogenic receptor $2(P 2 r \times 2)$ was expressed at significantly higher levels in the mouse OC and rat OC-LW than in the SG, LW, or MOD. As suggested by immunohistochemical data (Housley et al. 1999; Jarlebark et al. 2002), this channel is expressed in OHCs, Deiters, and SG type I cells and is upregulated in response to noise (Wang et al. 2003). The remaining genes are primarily associated with neuronal tissue. We found myelin proteolipid protein $(P l p)$ and neuronatin (Nnat) differentially expressed in the SG, whereas both Pmp22 and Limk1 transcripts were not significantly above background in all three dissected fractions.

Another study used the mouse Mu30K chip (Affymetrix, Santa Clara, CA) to examine differential expression between P2 and P32 mouse whole cochlea (Chen and Corey 2002a,b). There was little overlap between the Mu30 array and our CMA-IE1 chip. Only three genes could be compared that were developmentally upregulated in adult mice (Chen and Corey 2002a,b). These were connexin43 (Gja1), a twin-pore potassium ion channel (Kcnk1), and the $\mathrm{Na}^{+}, \mathrm{K}^{+}-$ activated ATP phosphohydrolase $\alpha 1$ subunit (Atp1a1). 
These genes appear to play a role, to varying degrees, in $\mathrm{K}^{+}$recirculation in the inner ear (Estevez et al. 2001; Liu et al. 2001; Wangemann 2002; Nicolas et al. 2003). We found higher levels of Gjal transcripts in the SG and LW compared with the OC. This reflects the tissue distribution of connexin 43 within the cochlea, in which these channels are mainly localized in the stria vascularis and spiral limbus (a component of the spiral ganglion fraction) (Suzuki et al. 2003; Cohen-Salmon et al. 2004). Both ATP1a1 and Kcnk1 (also designated as Twik-1) are ubiquitously expressed in all tissues (Orlowski and Lingrel 1988; Lesage et al. 1997) and are found in the ganglion, vestibular end organs, and the cochlea of the inner ear. However, immunohistochemistry studies have demonstrated that ATP1a1 and Kcnk1 are highly expressed in the marginal and vestibular dark cells. Both these proteins were shown at lower levels in the organ of Corti and spiral ganglion neurons (Zuo et al. 1995; Nicolas et al. 2003). We found higher levels of both these transcripts in the SG and OC compared with the LW, which does not appear to fit the protein expression patterns. Whole mount in situ hybridization and immunohistochemistry in combination with quantitative RT-PCR should help to resolve these discrepancies between transcript and protein expression levels as well as their associated cellular distribution patterns. Ideally, SAGE analyses (Gunnersen et al. 2002) of dissected cochlear fractions from adult mice should provide a more accurate depiction of the global transcript frequencies in these three fractions. Although these different semiquantitative expression platforms may provide limited comparative data, they still have demonstrated the usefulness of global expression analysis in the inner ear.

Our data demonstrate that differentially expressed genes can be identified among the three cochlear fragments and, in general, reflect their cellular, structural, cytoarchitectural, and functional disparities. Both the SG and LW fractions have a more limited cellular diversity compared with the OC. As noted in differential expression analyses, the cellular diversity is further reflected in the three groups of differentially expressed genes presented in Tables $3-5$. We categorized these genes from their general functional descriptors associated with their "gene ontology (GO) terms," which is based on function, process, and component characteristics of the gene products (Deng et al. 2004; Harris et al. 2004). The majority $(11 / 16 ; 68.8 \%)$ of differentially expressed genes in the SG are associated with neuronal tissues with three additional clones, secreted frizzled-related protein 4 (Sfrp4), chemokine ligand 12 (Cycl12), and breast cancer metastasis-suppressor 1-like (Brms1l), representing molecules involved in cellular development and proliferation. In the LW fraction, genes related to ion regulation and transport $(8 / 23 ; 32 \%)$ and those involved in cellular development and proliferation $(6 / 23 ; 24 \%)$ constitute the majority of differentially expressed genes. Both carbonic anhydrase genes (Car2 and Car14) and $\mathrm{Na}^{+}, \mathrm{K}^{+}$ATPase (Atp1b3) are all expressed in the lateral wall spiral ligament fibrocytes and are thought to play a role in cochlear fluid and ion homeostasis (Ichimiya et al. 1994; Spicer et al. 1997). $\mathrm{K}^{+}$homeostasis function of the marginal cells is mediated through the action of membrane proteins, such as $\mathrm{Na}^{+}, \mathrm{K}^{+}$ATPases, protein phosphatase inhibitors, and $\mathrm{Na}^{+}, \mathrm{K}^{+}, \mathrm{Cl}$ co-transporters (Zhao et al. 1994; Agrup et al. 1997; Spicer et al. 1997; Delpire et al. 1999; Dixon et al. 1999; Wangemann 2002). In the LW, we found a differentially expressed subunit of the protein phosphatase 1 regulatory (inhibitor) protein, Ppplr1b. This gene is likely associated with marginal cells. Another ion transporter, a sodium bicarbonate transporter (Slc4a11), was also identified in the lateral wall. One member of this family of genes, $\operatorname{Slc} 4 a 7$, was found to result in blindness and auditory impairment in mice that carry the targeted disrupted Slc4a7 gene (Bok et al. 2003) and was localized to fibroblasts in the spiral ligament, spiral prominence, and the suprastrial region. The functional properties of the differentially expressed genes associated with the OC were fairly diverse and likely are a reflection of the number and disparity of different cell types within the OC. As such, no one group of genes could be readily identified as being prevalent. To approximate the transcript frequency of the OC differentially expressed genes, we used the frequency of clones derived from the NIH organ of Corti cDNA library. By and large, gene expression levels ranged from moderate $[<10 \%$ of all the clones: otospiralin (Otos), otoraplin (Otor), and Sphase associated protein 1A (Skp1)], low to moderate [10-30\%: claudin 9 (Cldn9), dermatan sulfate proteoglycan 3 (Gspg3), and gelsolin (Gsn)], and the remainder, which were at a low level of occurrence. OC differentially expressed genes were also represented by three apparently low-frequency transcripts: nonspecific dipeptidase ( $\mathrm{Cn} 2)$ and two hypothetical proteins, MGC58343 and E130318F19Rik. These three genes were identified in the RIKEN subtracted library cDNAs but not in the organ of Corti cDNA clusters (Pompeia et al. 2004). Thus discrimination of differentially expressed transcripts could be detected regardless of the corresponding frequency.

Although the array was validated through differential expression analyses, detection of cell-unique and rare transcripts is still a major issue and is dependent on the complexity of the sample as well as quantity of starting material necessary for the generation of microarray probes. The small quantities of material obtained from either cells or dissected cochlear 
TABLE 5

\begin{tabular}{|c|c|c|c|c|}
\hline \multicolumn{5}{|c|}{ Lateral wall differentially expressed genes } \\
\hline Unigene & Name & $\begin{array}{l}\text { No. of clones } \\
\text { on array }\end{array}$ & $\begin{array}{l}\text { Average SAM score } \\
\quad(S G \text { vs. } L W)\end{array}$ & $\begin{array}{l}\text { Average SAM score } \\
\text { (OC vs. } L W)\end{array}$ \\
\hline $\mathrm{Mm} .226860^{\mathrm{a}}$ & $\begin{array}{l}\text { A430104C18Rik: RIKEN cDNA } \\
\text { A430104C18 gene }\end{array}$ & 2 & 13 & 16.9 \\
\hline Mm.1186 & Car2: carbonic anhydrase 2 & 1 & 15.2 & 11.5 \\
\hline Mm.210543 & $\begin{array}{l}\text { S/c4a11: solute carrier family } 4 \text {, sodium } \\
\text { bicarbonate transporter-like, member } 11\end{array}$ & 5 & 10.4 & 16.1 \\
\hline Mm.45372 & $\begin{array}{l}\text { Ppp1r1b: protein phosphatase } 1 \text {, regulatory } \\
\text { (inhibitor) subunit } 1 \mathrm{~B}\end{array}$ & 1 & 13.1 & 11.6 \\
\hline Mm. $44195^{\mathrm{a}}$ & $\begin{array}{l}\text { 1110011D13Rik: RIKEN cDNA } \\
2810003 \mathrm{C} 17 \text { gene }\end{array}$ & 7 & 13.4 & 10.6 \\
\hline Mm. $291826^{\mathrm{a}}$ & $\begin{array}{l}\text { 1110001I14Rik: RIKEN cDNA } \\
1110001 I 14 \text { gene }\end{array}$ & 1 & 12.5 & 8.1 \\
\hline Mm.277661 & $\begin{array}{l}\text { Lrpap1: low-density lipoprotein receptor- } \\
\text { related protein associated protein } 1\end{array}$ & 1 & 10.3 & 9.8 \\
\hline Mm.193539 & Hist1h1c: histone $1, \mathrm{H} 1 \mathrm{c}$ & 2 & 9.4 & 10 \\
\hline Mm. $24838^{\mathrm{a}}$ & $\begin{array}{l}\text { 2810003C17Rik: RIKEN cDNA } \\
\text { 2810003C17 gene }\end{array}$ & 2 & 8.6 & 10 \\
\hline Mm.306954 & Car14: carbonic anhydrase 14 & 2 & 9.7 & 8 \\
\hline Mm.41653 & Rlbp1: retinaldehyde binding protein 1 & 2 & 8.6 & 7.6 \\
\hline Mm.248616 & Mus musculus transcribed sequences & 2 & 6.7 & 8.6 \\
\hline Mm.227912 & Itpr1: inositol 1,4,5-triphosphate receptor 1 & 1 & 8.9 & 6 \\
\hline Mm.27035 & Qscn6: quiescin Q6 & 2 & 6.3 & 8 \\
\hline Mm.172346 & $\begin{array}{l}\text { Tgfbr2: transforming growth factor, beta } \\
\text { receptor II }\end{array}$ & 1 & 6.7 & 7.5 \\
\hline Mm.279256 & Ndr3: N-myc downstream regulated 3 & 1 & 6 & 8.1 \\
\hline Mm.20948 & Tcn2: transcobalamin 2 & 3 & 7 & 6.8 \\
\hline Mm.18526 & Ehd3: EH-domain containing 3 & 1 & 6.6 & 6.8 \\
\hline Mm.424 & $\begin{array}{l}\text { Atp 1b3: ATPase, } \mathrm{Na}+, \mathrm{K}+\text { transporting, beta } 3 \\
\text { polypeptide }\end{array}$ & 1 & 5.2 & 8.1 \\
\hline Mm.33240 & Eva: epithelial V-like antigen & 2 & 7.6 & 5.5 \\
\hline Mm.97885 & Bace2: beta-site APP-cleaving enzyme 2 & 2 & 6.9 & 5.5 \\
\hline Mm. $293605^{\mathrm{a}}$ & $\begin{array}{l}\text { 1110029F2ORik: RIKEN cDNA } \\
1110029 F 20 \text { gene }\end{array}$ & 2 & 5.8 & 5.8 \\
\hline Mm.9075 & Ephx1: epoxide hydrolase 1, microsomal & 1 & 5.2 & 6.3 \\
\hline F930001L18 & No Unigene ID & 1 & 9.1 & 9.6 \\
\hline F930113A03 & No Unigene ID & 1 & 6.4 & 10.8 \\
\hline gi36b05 & No Unigene ID & 1 & 8.2 & 8.5 \\
\hline gi25b04 & No Unigene ID & 1 & 9.7 & 6.0 \\
\hline
\end{tabular}

${ }^{\text {a}}$ These Unigene clusters represent hypothetical proteins.

tissues necessitate a twofold approach: the amplification of total RNA (Van Gelder et al. 1990; Baugh et al. 2001; Xiang et al. 2003) and a signal amplification of fluorescence signals using dendrimer technology (Stears et al. 2000). Both these strategies were incorporated in our studies. Because of the large number of different cell types and the low percentage of target cell types (e.g., hair cells) within the cochlea, it must be recognized that important rare to low-frequency inner-ear-pertinent transcripts are consequently diluted out in the sample. Methodologies for analysis of small sample sizes, representing single cell to small populations of a single cell type, are still evolving. Because of sampling error, the use of pristine populations of specific cell types is more desirable than single cell samples. Similarly, the statistical methods and approaches for normalization of the raw data and subsequent evaluation of microarray generated data (Tusher et al. 2001; Yang et al. 2002; Dudoit et al. 2003) require sufficient replication, which is difficult with single cell samples.

Microarrays can be used to identify genes that are expressed as well as upregulated or downregulated in the cochlea or its subsections to identify potential candidate deafness genes (Lomax et al. 2000; Chen and Corey 2002a,b; Iijima et al. 2004). Studies could also be designed to examine the expression profiles of mutants versus their wild-type counterparts to facilitate the discovery of genes involved in a hearing-related disorder. There are also a wide variety of developmental pathways and gene networks in the ear that could be delineated with microarray studies. 
Some examples are primary neuron formation and differentiation (Fritzsch and Beisel 2003) and the identification of downstream targets of transcription factors involved in hair cell formation and differentiation (Bryant et al. 2002; Hertzano et al. 2004). We will work to continually identify and add genes to the array representing unknown and/or uncharacterized transcripts from cochlear libraries to facilitate studies such as these.

\section{ACKNOWLEDGMENTS}

This work was supported in part by NIH grants R01 DC05009 (K.W.B, M.B.S.), DC04279 (K.W.B.), and a grant for the RIKEN Genome Exploration Research Project from the MEXT of the Japanese Government (Y.H.). We thank Dr. Bernd Fritzsch and Dr. Richard Hallworth for their comments and advice on this manuscript. We are also grateful to the technical assistance of Christine H. Halgard and Feng Feng.

\section{REFERENCES}

Abe S, Katagiri T, Saito-Hisaminato A, Usami S, Inoue Y, Tsunoda T, NAKAMURA Y. Identification of CRYM as a candidate responsible for nonsyndromic deafness, through cDNA microarray analysis of human cochlear and vestibular tissues. Am. J. Hum. Genet. 72:73-82, 2003.

Agrup C, Bagger-Sjoback D, Fryckstedt J. Protein kinase and protein phosphatase presence in the stria vascularis. Pflugers Arch. 433:603-608, 1997.

Ahmed ZM, Riazuddin S, Ahmad J, Bernstein SL, Guo Y, Sabar MF, Sieving P, Griffith AJ, Friedman TB, Belyantseva IA, et al. PCDH15 is expressed in the neurosensory epithelium of the eye and ear and mutant alleles are responsible for both USH1F and DFNB23. Hum. Mol. Genet. 12:3215-3223, 2003.

Badiee A, Eiken HG, Steen VM, Lovlie R. Evaluation of five different cDNA labeling methods for microarrays using spike controls. BMC Biotechnol. 3:23, 2003.

Baugh LR, Hill AA, Brown EL, Hunter CP. Quantitative analysis of mRNA amplification by in vitro transcription. Nucleic Acids Res. 29:E29, 2001.

Beisel KW, Shiraki T, Morris KA, Pompeia C, Kachar B, Arakawa T, Bono H, Kawai J, Hayashizaki Y, Carninci P. Identification of unique transcripts from a mouse full-length, subtracted inner ear cDNA library. Genomics 83:1012-1023, 2004.

Ben-Yosef T, Wattenhofer M, Riazuddin S, Ahmed ZM, Scott HS, Kudoh J, Shibuya K, Antonarakis SE, Bonne-Tamir B, RadhakRISHNA U, et al. Novel mutations of TMPRSS3 in four DFNB8/ B10 families segregating congenital autosomal recessive deafness. J. Med. Genet. 38:396-400, 2001.

Boeda B, El-Amraoui A, Bahloul A, Goodyear R, Daviet L, Blanchard S, Perfettini I, Fath KR, Shorte S, Reiners J, et al. Myosin VIIa, harmonin and cadherin 23, three Usher I gene products that cooperate to shape the sensory hair cell bundle. EMBO J. 21:6689-6699, 2002.

Bok D, Galbraith G, Lopez I, Woodruff M, Nusinowitz S, Beltrandel Rio H, Huang W, Zhao S, Geske R, Montgomery C, et al. Blindness and auditory impairment caused by loss of the sodium bicarbonate cotransporter NBC3. Nat. Genet. 34: 313-319, 2003.

BRYANT J, GOODYEAR RJ, RichaRdSON GP. Sensory organ development in the inner ear: molecular and cellular mechanisms. Br. Med. Bull. 63:39-57, 2002

Capaldi S, Getts RC, Jayasena SD. Signal amplification through nucleotide extension and excision on a dendritic DNA platform. Nucleic Acids Res. 28:E21, 2000.

Carninci P, Waki K, Shiraki T, Konno H, Shibata K, Itoh M, Aizawa $\mathrm{K}$, Arakawa T, Ishit Y, Sasaki D, et al. Targeting a complex transcriptome: the construction of the mouse full-length cDNA encyclopedia. Genome Res. 13:1273-1289, 2003.

Chen ZY, Corey DP. An inner ear gene expression database. J. Assoc. Res. Otolaryngol. 3:140-148, 2002a.

Chen ZY, Corey DP. Understanding inner ear development with gene expression profiling. J. Neurobiol. 53:276-285, $2002 \mathrm{~b}$.

Cho Y, Gong TW, Stover T, Lomax MI, Altschuler RA. Gene expression profiles of the rat cochlea, cochlear nucleus, and inferior colliculus. J. Assoc. Res. Otolaryngol. 3:54-67, 2002.

Churchill GA. Fundamentals of experimental design for cDNA microarrays. Nat. Genet. 32 (Suppl):490-495, 2002.

Cohen-Salmon M, Frenz D, Liu W, Verpy E, Voegeling S, Petit C. Fdp, a new fibrocyte-derived protein related to MIA/CD-RAP, has an in vitro effect on the early differentiation of the inner ear mesenchyme. J. Biol. Chem. 275:40036-40041, 2000.

Cohen-Salmon M, Maxeiner S, Kruger O, Theis M, Willecke K, Petit C. Expression of the connexin43- and connexin45-encoding genes in the developing and mature mouse inner ear. Cell Tissue Res. 316:15-22, 2004.

Delpire E, Lu J, England R, Dull C, Thorne T. Deafness and imbalance associated with inactivation of the secretory Na-K-2Cl co-transporter. Nat. Genet. 22:192-195, 1999.

Delprat B, Boulanger A, Wang J, Beaudoin V, Guitton MJ, Venteo S, Dechesne CJ, Pujol R, Lavigne-Rebillard M, Puel JL, et al. Downregulation of otospiralin, a novel inner ear protein, causes hair cell degeneration and deafness. J. Neurosci. 22:1718-1725, 2002.

Deng M, Tu Z, Sun F, Chen T. Mapping gene ontology to proteins based on protein-protein interaction data. Bioinformatics 20:895-902, 2004.

Dixon MJ, Gazzard J, Chaudhry SS, Sampson N, Schulte BA, Steel KP. Mutation of the $\mathrm{Na}-\mathrm{K}-\mathrm{Cl}$ co-transporter gene Slc12a2 results in deafness in mice. Hum. Mol. Genet. 8:1579-1584, 1999.

Dudoit S, Gentleman RC, Quackenbush J. Open source software for the analysis of microarray data. BioTechniques (Suppl.):45-51, 2003.

Estevez R, Boettger T, Stein V, Birkenhager R, Otto E, Hildebrandt $\mathrm{F}$, Jentsch TJ. Barttin is a $\mathrm{Cl}-$ channel beta-subunit crucial for renal $\mathrm{Cl}-$ reabsorption and inner ear $\mathrm{K}+$ secretion. Nature 414:558-561, 2001

Fritzsch B, Beisel KW. Molecular conservation and novelties in vertebrate ear development. Curr. Top. Dev. Biol. 57:1-44, 2003.

Glowatzki E, Wild K, Brandle U, Fakler G, Fakler B, Zenner HP, Ruppersberg JP. Cell-specific expression of the alpha 9 n-ACh receptor subunit in auditory hair cells revealed by singlecell RT-PCR. Proc. R. Soc. Lond., B Biol. Sci. 262:141-147, 1995.

Gunnersen JM, Augustine C, Spirkoska V, Kim M, Brown M, Tan SS. Global analysis of gene expression patterns in developing mouse neocortex using serial analysis of gene expression. Mol. Cell. Neurosci. 19:560-573, 2002.

Harris MA, Clark J, Ireland A, Lomax J, Ashburner M, Foulger R, Eilbeck K, Lewis S, Marshall B, Mungall C, et al. The gene ontology (GO) database and informatics resource. Nucleic Acids Res. 32 (Database issue):D258-D261, 2004 
Hawkins RD, Bashiardes S, Helms Ca, Hu L, Saccone NL, Warchol ME, LovetT M. Gene expression differences in quiescent versus regenerating hair cells of avian sensory epithelia: implications for human hearing and balance disorders. Hum. Mol. Genet. 12:1261-1272, 2003.

He Z, Tessier-Lavigne M. Neuropilin is a receptor for the axonal chemorepellent Semaphorin III. Cell 90:739-751, 1997.

Hegde P, Qi R, Abernathy K, Gay C, Dharap S, Gaspard R, Hughes JE, Snesrud E, Lee N, Quackenbush J. A concise guide to cDNA microarray analysis. BioTechniques 29:548-550, 552-544, 556 passim, 2000.

Hertzano R, Montcouquiol M, Rashi-Elkeles S, Elkon R, Yucel R, Frankel WN, Rechavi G, Moroy T, Friedman TB, Kelley MW, et al. Transcription profiling of inner ears from Pou4f3ddl/ ddl identifies Gfil as a target of the Pou4f3 deafness gene. Hum. Mol. Genet, 2004.

Housley GD, Kanjhan R, Raybould NP, Greenwood D, Salih SG, Jarlebark L, Burton LD, Setz VC, Cannell MB, Soeller C, et al. Expression of the P2X(2) receptor subunit of the ATP-gated ion channel in the cochlea: implications for sound transduction and auditory neurotransmission. J. Neurosci. 19:8377-8388, 1999.

Hume CR, KirkegaArd M, Oesterle EC. ErbB expression: the mouse inner ear and maturation of the mitogenic response to heregulin. J. Assoc. Res. Otolaryngol. 4:422-443, 2003.

ICHIMIYA I, ADAMS JC, KIMURA RS. Immunolocalization of Na+, $\mathrm{K}(+)-$ ATPase, $\mathrm{Ca}(++)$-ATPase, calcium-binding proteins, and carbonic anhydrase in the guinea pig inner ear. Acta Otolaryngol. 114:167-176, 1994.

Ijima N, Suzuki N, Oguchi T, Hashimoto S, Takumi Y, Sugahara K, Okuda T, Yamashita H, Usami S. The effect of hypergravity on the inner ear: CREB and syntaxin are up-regulated. NeuroReport 15:965-969, 2004.

Jarlebark Le, Housley GD, Raybould NP, Vlajkovic S, Thorne PR. ATP-gated ion channels assembled from P2X2 receptor subunits in the mouse cochlea. NeuroReport 13:1979-1984, 2002.

Judice TN, Nelson NC, Beisel Cl, Delimont DC, Fritzsch B, Beisel KW. Cochlear whole mount in situ hybridization: identification of longitudinal and radial gradients. Brain Res. Brain Res. Protoc. 9:65-76, 2002.

Kiernan Ae, Erven A, Voegeling S, Peters J, Nolan P, Hunter J, Bacon Y, Steel KP, Brown SD, Guenet JL. ENU mutagenesis reveals a highly mutable locus on mouse chromosome 4 that affects ear morphogenesis. Mamm. Genome 13:142-148, 2002.

Kikkawa Y, Shitara H, Wakana S, Kohara Y, Takada T, Okamoto M, Taya C, Kamiya K, Yoshikawa Y, Tokano H, et al. Mutations in a new scaffold protein Sans cause deafness in Jackson shaker mice. Hum. Mol. Genet. 12:453-461, 2003.

Knipper M, Bandtlow C, Gestwa L, Kopschall I, Rohbock K, Wiechers B, Zenner HP, Zimmermann U. Thyroid hormone affects Schwann cell and oligodendrocyte gene expression at the glial transition zone of the VIIIth nerve prior to cochlea function. Development 125:3709-3718, 1998.

Lee MJ, Calle E, Brennan A, Ahmed S, Sviderskaya E, Jessen KR, MIRSKY R. In early development of the rat mRNA for the major myelin protein $\mathrm{P}(0)$ is expressed in nonsensory areas of the embryonic inner ear, notochord, enteric nervous system, and olfactory ensheathing cells. Dev. Dyn. 222:40-51, 2001.

Lesage F, Lauritzen I, Duprat F, Reyes R, Fink M, Heurteaux C, Lazdunski M. The structure, function and distribution of the mouse TWIK-1 K+ channel. FEBS Lett. 402:28-32, 1997.

Liang Y, Chen H, Asher Jr. JH, Chang CC, Friedman TB. Human inner ear OCP2 cDNA maps to $5 \mathrm{q} 22-5 \mathrm{q} 35.2$ with related sequences on chromosomes 4p16.2-4p14, 5p13-5q22, 7pter-q22, 10 and 12p13-12qter. Gene 184:163-167, 1997.

Liberman MC, Gao J, He DZ, Wu X, Jia S, Zuo J. Prestin is required for electromotility of the outer hair cell and for the cochlear amplifier. Nature 419:300-304, 2002.

Liu XZ, Xia XJ, Adams J, Chen ZY, Welch KO, Tekin M, Ouyang XM, Kristiansen A, Pandya A, Balkany T, et al. Mutations in GJA1 (connexin 43) are associated with non-syndromic autosomal recessive deafness. Hum. Mol. Genet. 10:2945-2951, 2001.

Lomax MI, Huang L, Cho Y, Gong TL, Altschuler RA. Differential display and gene arrays to examine auditory plasticity. Hear. Res. 147:293-302, 2000.

Masmoudi S, Antonarakis SE, Schwede T, Ghorbel AM, Gratri M, Pappasavas MP, Drira M, Elgaied-Boulila A, Wattenhofer M, Rossier C, et al. Novel missense mutations of TMPRSS3 in two consanguineous Tunisian families with non-syndromic autosomal recessive deafness. Human Mutat. 18:101-108, 2001.

Mburu P, Mustapha M, Varela A, Weil D, El-Amraoui A, Holme RH, Rump A, Hardisty RE, Blanchard S, Coimbra RS, et al. Defects in whirlin, a PDZ domain molecule involved in stereocilia elongation, cause deafness in the whirler mouse and families with DFNB31. Nat. Genet. 34:421-428, 2003.

Nicolas MT, Barhanin J, Reyes R, Dememes D. Cellular localization of TWIK-1, a two-pore-domain potassium channel in the rodent inner ear. Hear. Res. 181:20-26, 2003.

Nolan PM, Peters J, Vizor L, Strivens M, Washbourne R, Hough T, Wells C, Glenister P, Thornton C, Martin J, et al. Implementation of a large-scale ENU mutagenesis program: towards increasing the mouse mutant resource. Mamm. Genome 11:500-506, 2000.

Okazaki Y, Furuno M, Kasukana T, Adachi J, Bono H, Kondo S, Nikaido I, Osato N, Saito R, Suzuki H, et al. Analysis of the mouse transcriptome based on functional annotation of 60,770 full-length cDNAs. Nature 420:563-573, 2002.

Onoe H, Ueno R, Fujita I, Nishino H, Oomura Y, Hayaishi O. Prostaglandin D2, a cerebral sleep-inducing substance in monkeys. Proc. Natl. Acad. Sci. USA. 85:4082-4086, 1988.

Orlowski J, Lingrel JB. Tissue-specific and developmental regulation of rat Na,K-ATPase catalytic alpha isoform and beta subunit mRNAs. J. Biol. Chem. 263:10436-10442, 1988.

Pompeia C, Hurle B, Belyantseva ia, Noben-Trauth K, Beisel K, Gao J, Buchoff J, Wistow G, Kachar B. Gene expression profile of the mouse organ of Corti at the onset of hearing. Genomics 83:1000-1011, 2004.

Rhodes CR, Parkinson N, Tsai H, Brooker D, Mansell S, Spurr N, Hunter AJ, Steel KP, Brown SD. The homeobox gene Emx2 underlies middle ear and inner ear defects in the deaf mouse mutant pardon. J. Neurocytol. 32:1143-1154, 2003.

Robertson NG, Heller S, Lin JS, Resendes BL, Weremowicz S, Denis CS, Bell AM, Hudspeth AJ, Morton CC. A novel conserved cochlear gene, OTOR: identification, expression analysis, and chromosomal mapping. Genomics 66:242-248, 2000.

Scherer A, Krause A, Walker JR, Sutton Se, Seron D, Raulf F, Cooke MP. Optimized protocol for linear RNA amplification and application to gene expression profiling of human renal biopsies. BioTechniques 34:546-550, 552-544, 556, 2003.

Scott HS, Kudoh J, Wattenhofer M, Shibuya K, Berry A, Chrast R, Guipponi M, Wang J, Kawasaki K, Asakawa S, et al. Insertion of beta-satellite repeats identifies a transmembrane protease causing both congenital and childhood onset autosomal recessive deafness. Nat. Genet. 27:59-63, 2001.

Siemens J, Lillo C, Dumont RA, Reynolds A, Williams DS, Gillespie PG, Muller U. Cadherin 23 is a component of the tip link in hair-cell stereocilia. Nature 428:950-955, 2004.

Sicer SS, Gratton MA, Schulte BA. Expression patterns of ion transport enzymes in spiral ligament fibrocytes change in relation to strial atrophy in the aged gerbil cochlea. Hear. Res. 111:93-102, 1997.

Stankovic KM, Corfas G. Real-time quantitative RT-PCR for low- 
abundance transcripts in the inner ear: analysis of neurotrophic factor expression. Hear. Res. 185:97-108, 2002.

Stears RL, GetTs RC, Gullans SR. A novel, sensitive detection system for high-density microarrays using dendrimer technology. Physiol. Genomics 3:93-99, 2000.

Suzuki T, Takamatsu T, Oyamada M. Expression of gap junction protein connexin 43 in the adult rat cochlea: comparison with connexin26. J. Histochem. Cytochem. 51:903-912, 2003.

Tusher VG, Tibshirani R, Chu G. Significance analysis of microarrays applied to the ionizing radiation response. Proc. Natl. Acad. Sci. USA 98:5116-5121, 2001.

Van Gelder RN, von Zastrow Me, Yool A, Dement WC, Barchas JD, EBerwine JH. Amplified RNA synthesized from limited quantities of heterogeneous cDNA. Proc. Natl. Acad. Sci. USA 87:1663-1667, 1990.

Wang JC, Raybould NP, Luo L, Ryan AF, Cannell MB, Thorne PR, Housley GD. Noise induces up-regulation of P2X2 receptor subunit of ATP-gated ion channels in the rat cochlea. NeuroReport 14:817-823, 2003.

WANGEMANN P. K+ cycling and the endocochlear potential. Hear. Res. 165:1-9, 2002.

Weil D, El-Amraoui A, Masmoudi S, Mustapha M, Kikkawa Y, Laine S, Delmaghani S, Adato A, Nadifi S, Zina ZB, et al. Usher syndrome type I G (USH1G) is caused by mutations in the gene encoding SANS, a protein that associates with the USH1C protein, harmonin. Hum. Mol. Genet. 12:463-471, 2003.
Wilson CL, Pepper SD, Hey Y, Miller CJ. Amplification protocols introduce systematic but reproducible errors into gene expression studies. BioTechniques 36:498-506, 2004.

Xiang CC, Chen M, Ma L, Phan QN, Inman JM, Kozhich OA, BrownsteIn MJ. A new strategy to amplify degraded RNA from small tissue samples for microarray studies. Nucleic Acids Res. 31:e53, 2003.

Yang YH, Dudoit S, Luu P, Lin DM, Peng V, Ngai J, Speed TP. Normalization for cDNA microarray data: a robust composite method addressing single and multiple slide systematic variation. Nucleic Acids Res. 30:e15, 2002.

Zhao H, Star RA, Muallem S. Membrane localization of $\mathrm{H}+$ and HCO3-transporters in the rat pancreatic duct. J. Gen. Physiol. 104:57-85, 1994.

Zheng J, Shen W, He DZ, Long KB, Madison LD, Dallos P. Prestin is the motor protein of cochlear outer hair cells. Nature 405:149-155, 2000.

Zuo J, Curtis LM, Yao X, Ten Cate WJ, Rarey Ke. Expression of Na, K-ATPase alpha and beta isoforms in the neonatal rat cochlea. Acta Otolaryngol. 115:497-503, 1995.

Zwaenepoel I, Mustapha M, Leibovici M, Verpy E, Goodyear R, Liu XZ, Nouaille S, Nance WE, Kanaan M, Avraham KB, et al. Otoancorin, an inner ear protein restricted to the interface between the apical surface of sensory epithelia and their overlying acellular gels, is defective in autosomal recessive deafness DFNB22. Proc. Natl. Acad. Sci. USA 99:6240-6245, 2002. 